\title{
Citridones, New Potentiators of Antifungal Miconazole Activity, Produced by Penicillium sp. FKI-1938
}

\author{
I. Taxonomy, Fermentation, Isolation and Biological Properties \\ Takashi Fukuda, Yuichi Yamaguchi, Rokuro Masuma, Hiroshi Tomoda, Satoshi Ōmura
}

Received: December 28, 2004 / Accepted: March 3, 2005

(C) Japan Antibiotics Research Association

\begin{abstract}
New phenylfuropyridinones and related compounds, designated citridones $\mathrm{A}, \mathrm{B}, \mathrm{B}^{\prime}$ and $\mathrm{C}$, were isolated along with known CJ-16,173, from the culture broth of Penicillium sp. FKI-1938 by solvent extraction, silica gel column chromatography and HPLC. Citridones $(75 \mu \mathrm{M})$ potentiate the miconazole activity against Candida albicans, decreasing the $\mathrm{IC}_{50}$ value of miconazole from $14.5 \mathrm{nM}$ to $3.5 \sim 6.3 \mathrm{nM}$.
\end{abstract}

Keywords citridones, anti-infective, azole potentiator, Penicillium

\section{Introduction}

Opportunistic infections caused by certain fungi, in particular problematic Candida albicans, have increased and studied the therapy of these infections [1]. Patients with compromised immune systems, e.g. patients receiving organ transplants and cancer chemotherapy, or those infected by human immunodeficiency virus (HIV), are particularly prone to such infections [1]. Recently, resistance to azole antifungals became a significant problem. Several resistant mechanisms have been proposed; 1) overexpression of transporters like ATP binding cassette $(\mathrm{ABC})$ transporter $[2], 2)$ mutation of

H. Tomoda (Corresponding author): School of Pharmaceutical Sciences, Kitasato University, 5-9-1 Shirokane, Minato-ku, Tokyo 108-8641, Japan, E-mail: tomoda@lisci.kitasato-u.ac.jp cytochrome P-450 14- $\alpha$ demethylase (P-450 14DM) [3], 3) overexpression of P450 14DM [4], and so on. Therefore, the resistant mechanisms will be a new target of inhibition for overcoming infections by azole-resistant $C$. albicans.

On the basis of new concept "antiinfective drugs" [5], we have discovered actofunicone [6] and beauvericins D, E and $\mathrm{F}[7,8]$, all produced by fungal strains, as potentiators of antifungal miconazole activity. The compounds showed no antimicrobial activity themselves, but reinforced miconazole activity against $C$. albicans. During the course of our continuous screening program, new compounds, designated citridones A, B, B' and C (Fig. 1), were isolated from the culture broth of Penicillium sp. FKI-1938 along with known CJ-16,173 [9]. All citridones potentiate miconazole activity against $C$. albicans (wild type).

In this paper, we describe the taxonomy of the producing fungus, fermentation, isolation and miconazolepotentiating activity of these citridones.

\section{Materials and Methods}

\section{General Experimental Procedures}

The strain FKI-1938 was isolated from soil collected on Ishigaki Island, Okinawa, Japan and was used for production of citridones and CJ-16,173. C. albicans

T. Fukuda, Y. Yamaguchi, R. Masuma, S. Ōmura: Kitasato Institute for Life Sciences \& Graduate School of Infection Control Sciences, Kitasato University, 5-9-1 Shirokane, Minato-ku, Tokyo 108-8641, Japan and The Kitasato Institute, 5-9-1 Shirokane, Minato-ku, Tokyo 108-8642, Japan 


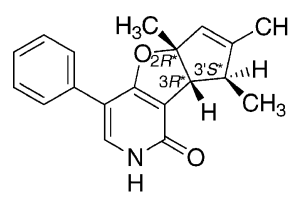

Citridone A

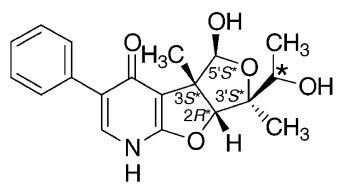

Citridone B

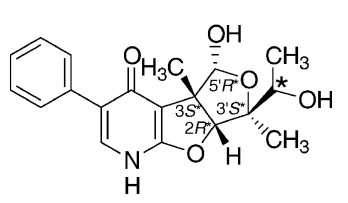

Citridone B'

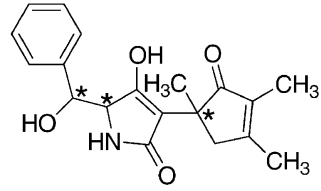

Citridone $\mathrm{C}$

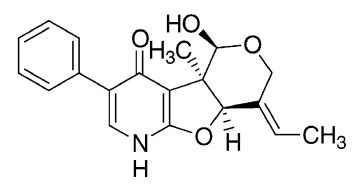

CJ-16,173

Fig. 1 Structures of citridones A, B, B', C and CJ-16,173.

ATCC64548 (wild type) were purchased from ATCC (Virginia, USA). For determination of the amounts of citridones $\mathrm{A}, \mathrm{B}, \mathrm{B}^{\prime}$ and $\mathrm{C}$ in the culture broths, the samples, dissolved in methanol, were analyzed on an HP 1100 system (Hewlett Packard Inc., Germany) under the following conditions: column, Symmetry $(2.1 \times 150 \mathrm{~mm}$, Waters Inc., Missouri, USA); flow rate, $0.2 \mathrm{ml} / \mathrm{minute}$; mobile phase, a 20-minute linear gradient from 30\%

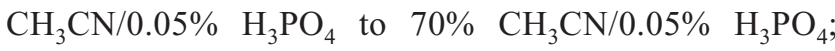
detection, $\mathrm{UV}$ at $210 \mathrm{~nm}$. Citridones $\mathrm{A}$ and $\mathrm{C}$ were eluted as peaks with retention times of 13.6 and 7.1 minutes, respectively. Citoridones $\mathrm{B}$ and $\mathrm{B}^{\prime}$ were found to exist in an equilibrium, eluting as broad peaks with a retention time of 3.2 3.9 minutes under the HPLC conditions. Packed cell volume (PCV) was measured after the whole culture broth at indicated times $(10 \mathrm{ml})$ was centrifuged at $3,000 \mathrm{rpm}$ for 10 minutes. The $\mathrm{pH}$ of the culture broth was measured by using compact $\mathrm{pH}$ meter (HORIBA).

\section{Taxonomic Studies of the Producing Organism}

Taxonomic studies and identification were conducted to the procedures described by Pitt [10]. Morphological observations were done under a light microscope (Olympus Vanox-S AH-2) and a scanning electron microscope (JEOL JSM-5600). Color names and hue numbers were determined according to the Color Harmony Manual [11].

\section{Assay for Miconazole-potentiating Activity}

Wild type of $C$. albicans was inoculated into a 50-ml test tube containing $10 \mathrm{ml}$ of seed medium (potato extract containing peptone $0.5 \%$ and glucose $1 \%$ ), and was grown for 24 hours on the rotary shaker. In Method A, the seed culture of C. albicans $(0.1 \%, \mathrm{v} / \mathrm{v})$ was transferred to the two different agar plates, GY agar (glucose 1\%, yeast extract $0.5 \%$ and agar $0.8 \%$ ) (Plate A) and GY agar plus miconazole $(0.06 \mu \mathrm{M})$ (Plate $\mathrm{B})$. The concentration $(0.06 \mu \mathrm{M})$ of miconazole is one fourth of the MIC value against $C$. albicans, and showed no effect on the growth of C. albicans. Paper disks ( $8 \mathrm{~mm}$, ADVANTEC, Tokyo, Japan) containing a sample were put on Plates A and B, which were incubated at $27^{\circ} \mathrm{C}$ for 24 hours. Samples showing inhibition zones selectively on Plate B were selected as potentiators of miconazole activity against $C$. albicans. In Method B, the broth microdilution test using 96-well microplates (Corning, New York, USA) was performed according to the guidelines of NCCLS document M27-A [12]. Five colonies of wild C. albicans with diameters of $1 \mathrm{~mm}$ were suspended in sterile $0.85 \%$ saline to adjust to a 0.5 McFarland standard by spectrophotometric measurement. The seed of $C$. albicans was diluted 1,000 times with medium A $(165 \mathrm{mM}$ morpholinopropanesulfonic acid buffer $(\mathrm{pH} 7.0)$ ), and the diluted seed $(100 \mu \mathrm{l})$ containing serial concentration of miconazole $(0 \sim 80 \mathrm{nM})$ in the absence or presence of a sample $(75 \mu \mathrm{M})$ to make the total volume $200 \mu \mathrm{l} /$ well. $C$. albicans in microplates was incubated at $27^{\circ} \mathrm{C}$ for 24 hours, and the growth of C. albicans was measured at $630 \mathrm{~nm}$ with a microplate reader (model Elx 808, BIO-TEK Instruments, Vermont, USA). The $\mathrm{IC}_{50}$ values of miconazole against $C$. albicans in the absence or presence of a sample were calculated.

\section{Results}

\section{Taxonomy of the Producing Strain FKI-1938}

Strain FKI-1938 was originally isolated from a soil sample collected at Ishigakijima Island, Okinawa Perfecture, Japan. 


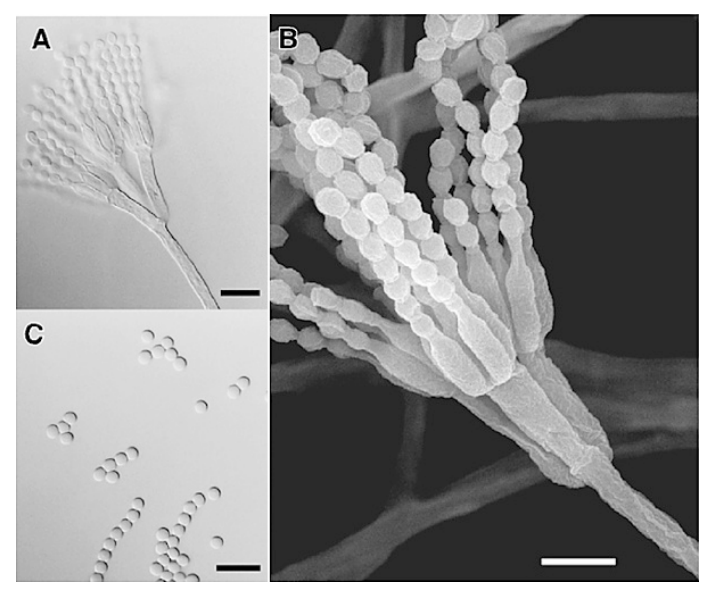

Fig. 2 Penicillium sp. FKI-1938 on CYA. (A) Biverticillate penicilli under a light microscope. (B) Biverticillate penicilli and conidia under a scanning electron microscope. (C) Conidia under a light microscope. Scale bar: A, C; $10 \mu \mathrm{m}, \mathrm{B}$; $5 \mu \mathrm{m}$.

For the taxonomic studies of fungus, Czapek yeast extract agar (CYA), malt extract agar (MEA) and 25\% glycerol nitrate agar $(\mathrm{G} 25 \mathrm{~N})$ were used. Colonies on CYA were $30 \sim 36 \mathrm{~mm}$ diameter after 7 days at $25^{\circ} \mathrm{C}$, floccose to velutinous, radially sulcate, sage gray ( $24 \mathrm{ih}$ ) to mistletoes gray (24 1/2 ih) in color. The reverse side was bamboo $(2 \mathrm{gc})$ to cream $(11 / 2 \mathrm{ca})$. Colonies on MEA were $20 \sim 22 \mathrm{~mm}$ diameter, velutinous, plane to light radially sulcate, dark olive green $(241 / 2 \mathrm{nl})$ to mistletoes green (24 1/2 li) in color. The reverse side was bamboo ( $2 \mathrm{gc})$ to covert tan $(11 / 2 \mathrm{ca})$. Colonies on G25N were $19 \sim 21 \mathrm{~mm}$ diameter, floccose to velutinous, radially sulcate, celadon gray ( $24 \mathrm{fe})$ to sage gray $(24 \mathrm{ih})$ in color. The reverse side was pearl pink ( $3 \mathrm{ca}$ ) to light yellow $(2 \mathrm{ea})$. At $5^{\circ} \mathrm{C}$ and $37^{\circ} \mathrm{C}$, on CYA colonies were no growth. Soluble pigment was not produced on each medium. Conidiogenesis on each medium was moderate to abundant. Conidiophores on CYA were borne from subsurface or aerial hyphae, with 150 500 $(\sim 800) \mu \mathrm{m}$ long, smooth-walled, and bearing biverticillate penicilli. Metulae were in $(2 \sim) 3 \sim 4$ divergent clusters and $14 \sim 18 \times 2.8 \sim 3.5 \mu \mathrm{m}$ in size (Fig. $2 \mathrm{~A}, 2 \mathrm{~B}$ ). Phialides were $5 \sim 8$ per metula, ampulliform with $8 \sim 11 \times 2 \sim 3 \mu \mathrm{m}$ in size and smooth-walled (Fig. 2A). Conidia after 7 days incubation, were spherical to subsperical, 2.3 3.0 $\mu \mathrm{m}$, smooth-walled, and in divergent long chains (Fig. 2B, 2C). From the above characteristics, strain FKI-1938 was considered to belong to the genus Penicillium and named it Penicillium sp. FKI-1938. Futhemore, the strain was considered to be classified in Penicillium citrinum series that are characterized by conidiophore are smooth walled and divergent whorls of

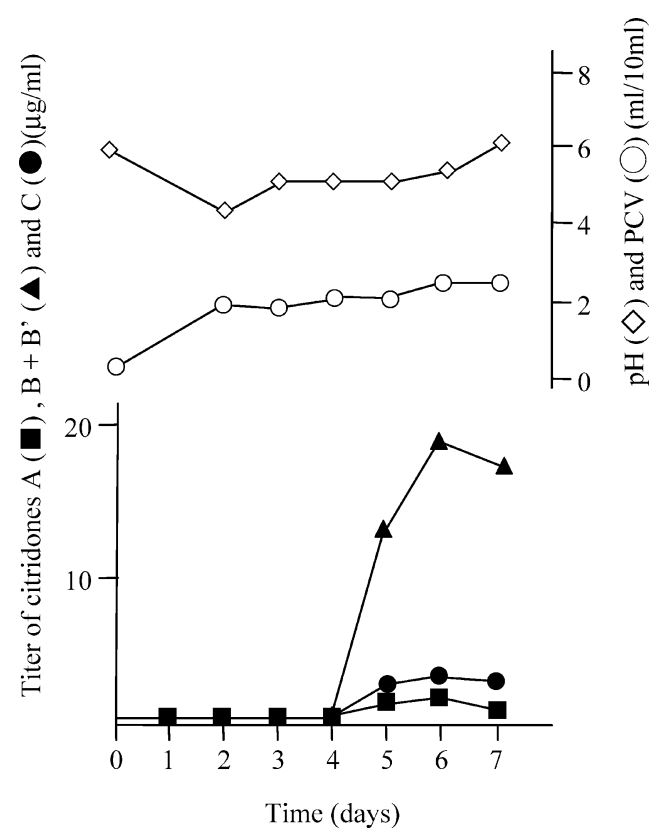

Fig. 3 A typical time course of citridone production by Penicillium sp. FKI-1938. The amounts of citridones $A(\square)$, $\mathrm{B}+\mathrm{B}^{\prime}(\mathbf{\Delta})$ and $\mathrm{C}(\mathbf{O}), \mathrm{PCV}(\bigcirc)$ and $\mathrm{pH}(\diamond)$ in culture broths were determined as described in Materials and Methods.

metulae usually without further branches; conidia are globose to subglobose, smooth walled and not exceeding $3 \mu \mathrm{m}$ diameter $[13,14]$. The strain has been deposited to the National Institute of Bioscience and HumanTechnology, Agency of Industrial Science and Technology Japan, as FERM ABP-10149.

\section{Fermentation}

A slant culture of the strain FKI-1938 grown on LcA medium (glycerol $0.1 \%, \mathrm{KH}_{2} \mathrm{PO}_{4} 0.08 \%, \mathrm{~K}_{2} \mathrm{HPO}_{4} 0.02 \%$, $\mathrm{MgSO}_{4} \cdot 7 \mathrm{H}_{2} \mathrm{O} 0.02 \%, \mathrm{KCl} 0.02 \%, \mathrm{NaNO}_{3} 0.2 \%$, yeast extract $0.02 \%$ and agar $1.5 \%, \mathrm{pH} 6.0$ ) was used to inoculate a $500-\mathrm{ml}$ Erlenmeyer flask containing $100 \mathrm{ml}$ of the seed medium (glucose $2.0 \%$, yeast extract $0.2 \%, \mathrm{MgSO}_{4} \cdot 7 \mathrm{H}_{2} \mathrm{O}$ $0.05 \%$, polypepton $0.5 \%, \mathrm{KH}_{2} \mathrm{PO}_{4} 0.1 \%$ and agar $0.1 \%$, pH 6.0). The flask was shaken on a rotary shaker at $27^{\circ} \mathrm{C}$ for 3 days. The seed culture $(100 \mathrm{ml})$ was transferred into a 7.5 liter jar fermenter (B. E. Marubishi, Japan) containing 5 liters of the production medium (glycerol 2.0\%, sucrose $1.0 \%$, ammonium acetate $0.5 \%, \quad \mathrm{~K}_{2} \mathrm{HPO}_{4} \quad 0.1 \%$, $\mathrm{MgSO}_{4} \cdot 7 \mathrm{H}_{2} \mathrm{O} 0.05 \%$, KCl $0.05 \%$, Cultivater \#100 (Yazu Suisankagaku Industry CO., LTD.) $0.2 \%$ and agar $0.1 \%$, pH 6.0). The fermentation was carried out at $27^{\circ} \mathrm{C}$ for 7 days with an aeration of 2.5 liters/minute and an agitation of $200 \mathrm{rpm}$.

A typical time course of the fermentation is shown in Fig. 3. Citridone A, the mixture of citridones $\mathrm{B}$ and $\mathrm{B}^{\prime}$, and 


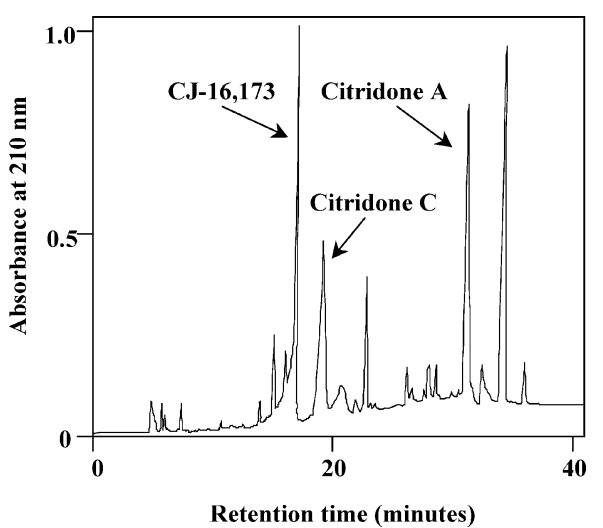

Fig. 4 A chromatographic profile of purification of citridones A and C by preparative HPLC. Column, Senshu Pak PEGASIL ODS $(4.6 \times 250 \mathrm{~mm})$; solvent, 40-minute linear gradient from 30 to $70 \% \mathrm{CH}_{3} \mathrm{CN}$ in $0.05 \% \mathrm{H}_{3} \mathrm{PO}_{4}$; detection, UV at $210 \mathrm{~nm}$; flow rate, $1.0 \mathrm{ml} /$ minute; sample, $10 \mu \mathrm{g}$ of active materials dissolved in $10 \mu \mathrm{l}$ of $\mathrm{MeOH}$.

citridone $\mathrm{C}$ were detected in the culture broth from day 5 after inoculation, and their concentrations reached a maximum (1.3, 19.3 and $2.6 \mu \mathrm{g} / \mathrm{ml}$, respectively) on day 6 .

\section{Isolation}

To the 7-day old culture broth (5 liters) was added acetone (5 liters). After the acetone extracts were filtered and concentrated, the resulting aqueous solution was extracted with ethyl acetate (5 liters). The ethyl acetate layer was dried over $\mathrm{Na}_{2} \mathrm{SO}_{4}$ and concentrated in vacuo to dryness to yield an oily material $(2.9 \mathrm{~g})$. The material was dissolved in a small volume of $\mathrm{CHCl}_{3}$, applied on a silica gel column $(60 \mathrm{~g}, 3.4 \times 28 \mathrm{~cm}, 70 \sim 230 \mathrm{mesh}$, Merck $)$, and eluted stepwise with $100: 0,100: 1,75: 1,50: 1,40: 1,30: 1$, $10: 1$ and $0: 100(\mathrm{v} / \mathrm{v})$ of $\mathrm{CHCl}_{3}-\mathrm{CH}_{3} \mathrm{OH}$ solvents $(1000 \mathrm{ml}$ each). The miconazole-potentiating activity was observed in the $100: 1$ fraction, which was concentrated to give a brown material $(237.5 \mathrm{mg})$. The material was purified by HPLC; ODS column $(4.6 \times 250 \mathrm{~mm}$, Pegasil, Senshu Sci. Co. Tokyo, Japan), a 40-minute linear gradient from 30 to $70 \% \mathrm{CH}_{3} \mathrm{CN}$ in $0.05 \% \mathrm{H}_{3} \mathrm{PO}_{4}, 1.0 \mathrm{ml} /$ minute, and $U V$ at $210 \mathrm{~nm}$. Under the conditions, citridones $\mathrm{A}$ and $\mathrm{C}$ were eluted as peaks with retention times of 32.0 and 18.8 minutes, respectively (Fig. 4). Each peak was collected and concentrated to yield citridone $\mathrm{A}(6.4 \mathrm{mg})$ as white needles and citridone $\mathrm{C}(11.7 \mathrm{mg})$ as pale yellow amorphous. The 50:1 fraction (white powder) was recrystallized from $\mathrm{MeOH}$ to give a mixture of citridones $\mathrm{B}$ and $\mathrm{B}^{\prime}(59.2 \mathrm{mg})$ as white needles. Analysis of the mixture by HPLC as described (HP 1100 system) showed broad two peaks with a retention time of 3.2 3.9 minutes. Each peak
Table 1 Potentiation of miconazole activity against $C$. albicans by citridones and CJ-16,173

\begin{tabular}{|c|c|c|c|}
\hline \multirow{2}{*}{ Compound } & \multirow{2}{*}{$\frac{\text { Concentration }}{\mu \mathrm{g} / \text { disk }}$} & \multicolumn{2}{|c|}{ Inhibition zone (mm) } \\
\hline & & Plate A & Plate B \\
\hline \multirow[t]{3}{*}{ Citridone A } & 10 & - & 17 \\
\hline & 25 & - & 19 \\
\hline & 50 & - & 23 \\
\hline \multirow[t]{3}{*}{ Citridones $\mathrm{B}+\mathrm{B}^{\prime}$} & 10 & - & - \\
\hline & 25 & - & 13 \\
\hline & 50 & - & 15 \\
\hline \multirow[t]{3}{*}{ Citridone C } & 10 & - & - \\
\hline & 25 & - & 11 \\
\hline & 50 & - & 17 \\
\hline \multirow[t]{3}{*}{ CJ-16,173 } & 10 & - & - \\
\hline & 25 & - & - \\
\hline & 50 & - & - \\
\hline
\end{tabular}

Paper disks (8 $\mathrm{mm}$ i.d.) containing three concentrations of a compound were put on Plate A (C. albicans in GY agar) and Plate B (C. albicans in $\mathrm{GY}$ agar $+0.06 \mu \mathrm{M}$ miconazole), and incubated at $27^{\circ} \mathrm{C}$. After 24 hours, the diameters of inhibition zones were measured (Method A). The concentration $(0.06 \mu \mathrm{M})$ of miconazole is one fourth of the MIC value against $C$. albicans, and showed no effect on the growth of $C$. albicans.

Table 2. Reinforcement of miconazole activity against $C$. albicans by citridones.

\begin{tabular}{ccc}
\hline \multicolumn{1}{c}{ Addition } & $\begin{array}{c}\text { IC } 50 \text { of miconazole } \\
(\mathrm{nM})\end{array}$ & $\begin{array}{c}\text { Ratio } \\
\text { (control/+drug) }\end{array}$ \\
\hline None (control) & 14.5 & 1 \\
+ Citridone A & 5.0 & 2.9 \\
+ Citridones B+B' & 6.0 & 2.4 \\
+ Citridone C & 3.5 & 4.1 \\
+ CJ-16,173 & 6.3 & 2.3 \\
\hline
\end{tabular}

The $I C_{50}$ value of miconazole against the growth of $C$. albicans in the absence (control) or presence of a compound $(75 \mu \mathrm{M})$ were measured using 96-well microplates (Method B).

collected was analyzed under the same condition, showing the same broad two peaks. As described in the preceding paper [15], citridones $\mathrm{B}$ and $\mathrm{B}^{\prime}$ existed in equilibrium (about $3: 2$ ) of hemiacetal epimerization in a solution, and could not be separated.

\section{Biological Properties Miconazole-potentiating Activity by Citridones}

The miconazole-potentiating activity of citridones was tested by Methods A and B. In Method A, all citridones 
themselves showed no inhibition against wild $C$. albicans at up to $50 \mu \mathrm{g} /$ disk on Plate A. However, all citridones gave dose-dependent inhibition zones on Plate B (Table 1). These results indicated that citridones potentiate miconazole activity against wild C. albicans. However, under the similar methods no potentiation of miconazole activity by citridones was observed against Aspergillus and Mucor.

Potentiation of miconazole activity by citridones was evaluated by Method $\mathrm{B}$. The $\mathrm{IC}_{50}$ values of all citridones against C. albicans were over $400 \mu \mathrm{M}$ (data was not shown). In the absence of citridones, the $\mathrm{IC}_{50}$ value of miconazole against $C$. albicans was calculated to be $14.5 \mathrm{nM}$. In combination with citridone $\mathrm{A}$, a mixture of citridones B and B', citridone C and CJ-16,173 (75 $\mu \mathrm{M}$ each), the respective $\mathrm{IC}_{50}$ values of miconazole were decreased to 5.0, 6.0, 3.5 and $6.3 \mathrm{nM}$ (Table 2). Thus, it was confirmed that they potenitate miconazole activity against C. albicans.

\section{Discussion}

Several phenylfuropyridines or phenylfuropyridones such as CJ-15,696 (cladobotryal), CJ-16,170, CJ-16,171 and CJ16,173, structurally related to citridones A, B and B' (Fig. 1) were isolated from Caldobotrium varium $[9,16]$. Such known ones have linked ring systems $(6-6 / 5$ or $6-6 / 5 / 6)$, which were different from the citridones' $(6-6 / 5 / 5)$. But the citridones-producing Penicillium sp. FKI-1938 also produced CJ-16,173 as described in this paper. Among the CJ compounds, CJ-15,696 was reported to possess moderate activity against various Gram-positive bacteria including some drug-resistant strains [9]. Citridones and CJ-16,173 showed no activity even at $1 \mathrm{mg} / \mathrm{ml}$ against 15 microorganisms including Gram-positive bacteria (Bacillus subtillis, Staphylococcus aureus, Mycobacterium smegmatis and Micrococcus luteus) and Gram-negative bacteria (Escherichia coli, Escherichia coli CJ-2, Xanthomonas oryzae, Pseudomonas aeruginosa, Bacteroides fragilis and Acholeplasma laidlawii), fungi (Mucor racemosus, Aspergillus niger and Pyricularia oryzae) and yeast (C. albicans and Saccharomyces cerevisiae). However, we found that they potentiate antifungal miconazole activity against $C$. albicans (Table 2). Among them, citridone $C$ having an isolated-ring system showed the most potentiating activity. It might be interesting whether or not CJ compounds show the miconazole potentiating activity to study the structureactivity relationship.
Acknowledgment This study was supported in part by the 21st Century COE Program and Kakenhi 16073215, Ministry of Education, Culture, Sports, Science and Technology, Japan.

\section{References}

1. Nishiyama Y, Yamaguchi H. Made of action of antifungal agents for treatment of systematic fungal infection. Antibiot Chemother 16: 19-26 (2000)

2. Walsh TJ, Kasai M, Francesconi A, Landsman D, Chanock SJ. New evidence that Candida albicans possesses additional ATP-binding cassette MDR-like genes: implications for antifungal azole resistance. J Med Vet Mycol 35: 133-137 (1997)

3. Fling ME, Kopf J, Tamarkin A, Gorman JA, Smoth HA, Koltin Y. Analysis of a Candida albicans gene that encodes a novel mechanism for resistance to benomyl and methotrexate. Mol Gen Genet 227: 318-329 (1991)

4. Bossdhe HV, Marichal P, Gorrens J, Bellens D, Moereels H, Janssen PAJ. Mutation in cytochrome-P-450-dependent $14 \alpha$-demethylase results in decreased affinity for azole antifungals. Bio Chem Soc Trans 18: 56-59 (1990)

5. Ōmura S. Antiinfective drugs into the 21 st century. Nippon Saikingaku Zasshi 54: 795-813 (1999) (in Japanese)

6. Arai M, Tomoda H, Okuda T, Wang H, Tabata N, Masuma R, Yamaguchi Y, Ōmura S. Funicone-related compounds, potentiators of antifungal miconazole activity, prodused by Talaromyces flavus FKI-0067. J Antibiot 55: 172-180 (2002)

7. Fukuda T, Arai M, Yamaguchi Y, Masuma R, Tomoda H, Ōmura S. New beauvericins, potentiators of antifungal miconazole activity, produced by Beauveria sp. FKI-1366. I. Taxonomy, fermentation, isolation, and biological properties. J Antibiot 57: 110-116 (2004)

8. Fukuda T, Arai M, Tomoda H, Ōmura S. New beauvericins, potentiators of antifungal miconazole activity, produced by Beauveria sp. FKI-1366. II. Structure elucidation. J Antibiot 57: 117-124 (2004)

9. Sakemi S, Border J, Decosta DL, Dekker KA, Hirai H, Inagaki T, Kim YJ, Kozima N, Sims JC, Sugie Y, Sugiura A, Sutcliffe JA, Tachikawa K, Truesdell SJ, Wong JW, Toshikawa N, Kozima Y. CJ-15,696 and its analogs, new furopyridine antibiotics from the fungus Cladobotryum varium: fermentation, isolation, structural elucidation, biotransformation and antibacterial activities. J Antibiot 55: 6-18 (2002)

10. Pitt JI. A laboratory guide to common Penicillium species, 3rd ed. Food Science Australia (2000)

11. Taylor HD, Knoche L, Granville WC. Color Harmony Manual 4th Ed. Container of America, Chicago (1958)

12. National Committee Clinical Laboratory Standards. Approved Standard M27-A. NCCLS Villanova PA. (1997)

13. Raper KB, Thom C, Fennel DI. A manual of the Penicillia. The Williams and Wilkins Co., Baltimore (1949) 
14. Domsch KH, Gams W, Anderson TH. Compendium of soil fungi, Vol. 1. Academic Press, London, pp. 541-611 (1993)

15. Fukuda T, Tomoda H, Ōmura S. Citridones, new potentiators of antifungal miconazole activity, produced by Penicillium sp. FKI-1938. II. Structure elucidation. J Antibiot 58:
315-321 (2005)

16. Breinholt J, Jensen HC, Kjaer A, Olsen CE, Rassing BR, Rosendahl CN, Sotofte I. Cladobotryal: a fungal metabolite with a novel ring system. Acta Chem Scand 52(5): 631-634 (1998) 